\title{
ANALYTICAL ESTIMATION OF WATER QUALITY INDEX IN INDUSTRIAL ESTATE BHILAI, CHHATTISGARH AND CORRELATION BETWEEN VARIOUS WATER QUALITY PARAMETERS
}

\author{
M. Upadhyay ${ }^{1}$ and M. K. Jindal ${ }^{2, *}$ \\ ${ }^{1}$ Principal, Dr. C. V. Raman University, Kota, Bilaspur, 495113, (Chhattisgarh) India \\ ${ }^{2}$ Department of Chemistry, Indian Institute of Technology Bhilai, 492015, (Chhattisgarh) India \\ *E-mail:manoj@iitbhilai.ac.in
}

\begin{abstract}
The present investigation estimates the Water Quality Index (WQI) for groundwater near to industrial estate Bhilai, Durg District Chhattisgarh. The Water Quality Index was investigated by taking eleven parameters TDS, $\mathrm{pH}$, Turbidity, Total Alkalinity, Total Hardness, Calcium, Magnesium, Chloride, DO, BOD and COD. It was observed that the Water Quality Index values varied from 69.79 to 141.71 . The value of the Water Quality Index in some areas shows the sample was unsuitable because of the high concentration of TDS, Hardness and COD. This study indicates a correlation between TDS vs. Chloride, BOD, Total Hardness and found a positive correlation among them except COD. The water quality index value of groundwater samples near to industries was unfit for drinking purpose, without any suitable treatment.
\end{abstract}

Keywords: Water Quality Index (WQI), Industrial Estate, Ground Water, Correlation

(c) RASĀYAN. All rights reserved

\section{INTRODUCTION}

Water is the precious, indispensable and dynamic renewable natural resource and water is often polluted in various ways. ${ }^{1-6}$ The quality of groundwater is a most important for improving the quality of life. ${ }^{7}$ The quality of water is describe by Chemical, Physical and Biological properties. ${ }^{2}$ Based on World Health Organization (WHO) reports, diarrhea is a major killer in poor and developing countries approximately 4 billion cases of diarrhea worldwide reported each year and 2.2 million people killed annually, mostly children who were under 5 years of age and in living beings especially in human approx. $80 \%$ disease is found due to water. ${ }^{8-10}$ The overall quality of water can easily estimate by the Water Quality Index. ${ }^{11}$ One of the most serious environmental issues for the twenty-first century is clean and potable drinking water. ${ }^{12}$ The water ecosystem has altered in several respects in the last decades due to the tremendous development in agriculture and industry. ${ }^{13}$ Water quality is considered as an important factor for the judgment of environmental changes that are associated with economic and social development. ${ }^{1}$ The studied data of various physiochemical parameters are useful for the study of the nature of the water environment. This type of study will be beneficial for the proper management strategies and monitoring of water quality assessment. ${ }^{12}$ This study will provide specific information about the water quality of the industrial area.

\section{Selection of the Study Area}

\section{EXPERIMENTAL}

Water pollution arises due to an increase in the population, developing industries and urbanization. Details of the sampling station are shown in Table-1. Due to rapid changes in industrialization, it is necessary to monitor environmental pollution. Bhilai city is famous for the industries, so it has been selected as a study point. Bhilai is a famous area in the Durg District, Chhattisgarh, India. Bhilai city is located $25 \mathrm{~km}(16 \mathrm{mi})$ at the National Highway- 6 in the west of the capital city of Raipur. Based on the 2011 census, the total population of the city Durg-Bhilai was $1,064,077 .{ }^{14}$

Rasayan J. Chem., 13(3), 1777-1784(2020)

http://dx.doi.org/10.31788/ RJC.2020.1335853 
RASĀYAN J. Chem.

Vol. 13 | No. 3 |1777-1784| July - September | 2020

Table-1: Detail of Sampling Station

\begin{tabular}{c|c|c}
\hline Sample Code & Sampling Location Detail & Latitude and Longitude \\
\hline $\mathrm{GW}_{1}$ & Near to Jaypee Cement Bhilai & $21.186266,81.358830$ \\
\hline $\mathrm{GW}_{2}$ & Near to BE Industry & $21.227744,81.386734$ \\
\hline $\mathrm{GW}_{3}$ & Near to Bhilai Engineering Corporation & 21.231581 .3828 \\
\hline $\mathrm{GW}_{4}$ & Rajiv Nagar Near to ACC Company & $21.235316,81.388754$ \\
\hline $\mathrm{GW}_{5}$ & Near to Simplex Industry & $21.232795,81.383566$ \\
\hline $\mathrm{GW}_{6}$ & Near to Shivnath Industry & $21.228662,81.392785$ \\
\hline $\mathrm{GW}_{7}$ & Near to Beekay Industry & $21.234581,81.377448$ \\
\hline
\end{tabular}

About fifty thousand people come to Bhilai city in the Industrial area for employment because this city is surrounded by various industries. The work done at Bhilai is mainly in BSP. Other big and established units are Bhilai Engineering Corporation, Associated Cement Company (ACC), Simplex Engineering, Beekay Engineering, Jaypee Cement Bhilai and Automation etc. The sampling points are shown in Fig.-1.
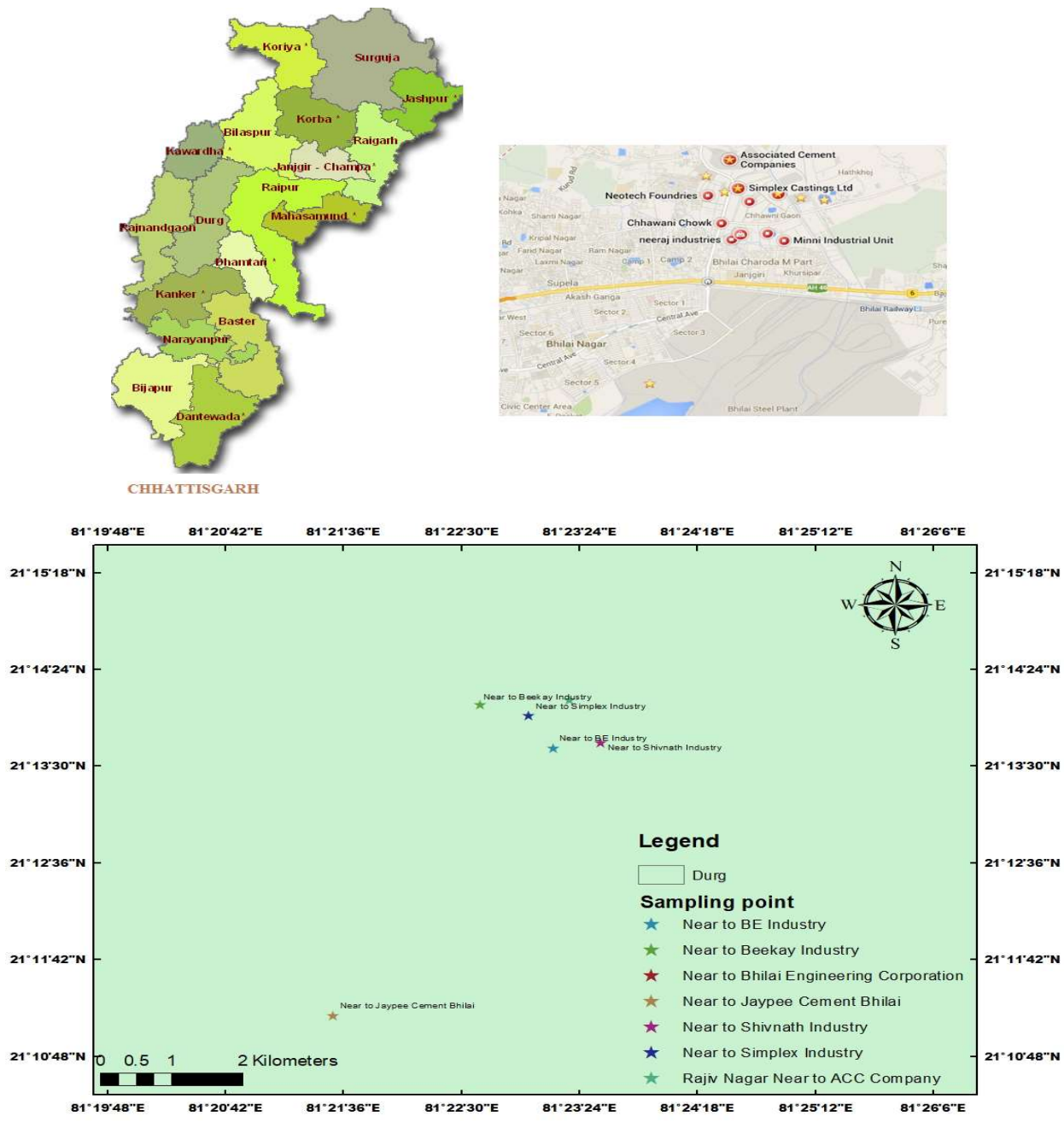

Fig.-1: Location of Study Spot Bhilai, Chhattisgarh India

\section{Collection of Samples}

The water samples were collected near to industrial area Bhilai from seven sampling points $\mathrm{GW}_{1}, \mathrm{GW}_{2}$, $\mathrm{GW}_{3}, \mathrm{GW}_{4}, \mathrm{GW}_{5}, \mathrm{GW}_{6}$ and $\mathrm{GW}_{7}$. Polythene bottles were used for the collection of water samples, which were rinsed with $2 \%$ nitric acid and more than two times rinse with distilled water. ${ }^{15}$ The sample bottles were immediately send in laboratory. ${ }^{16-17}$ The standard methods were adopted for various water quality parameters. $\mathrm{pH}$ values of samples were determined by the apparatus of $\mathrm{pH}$ meter used with a buffer solution of 4,7 and $9.2 \mathrm{pH}$. The turbidity meter was utilized for the measurement of turbidity of water 
RASĀYAN J. Chem.

Vol. 13 | No. 3 |1777-1784| July - September | 2020

samples. Standard solutions of 200 NTU and 400 NTU were prepared by using Hydrazine sulphate and Hexamethylene Tetramine. TDS values were measured by TDS meter, whereas TS and TSS were analyzed by the classical method. EDTA method was adopted for the determination of Total Hardness, Magnesium and Calcium Hardness by using EBT and Patton and Reader as an indicator. Acid-Base titration method was used for estimation of Total Alkalinity and Total Acidity by the use of Phenolphthalein and Methyl-Orange as an indicator. Agentometric titration method was used for the determination of Chloride with the help of Standard N/50 Silver Nitrate solution. Winkler method was used for the analysis of DO contain in the water sample. For the determination of BOD, the BOD incubator was used to incubate the sample for 3 days at $27^{\circ} \mathrm{C}$. COD test was carried out by the Refluxing of the sample for 2 hours in the presence of excess acidified potassium dichromate solution. ${ }^{18}$

\section{Water Quality Index}

WQI (Water Quality index) is an essential tool for monitoring the quality of groundwater pollution. This index has been accepted as a rating because it can show the overall effect of the precise quality of water. ${ }^{19}$ WQI gives information about a rating scale of zero to a hundred. The arithmetic water quality index is used to determine the status of water quality. ${ }^{20}$ Eleven water quality parameters Total Dissolved Solids (TDS), pH, Chloride, Turbidity, Total Hardness, Total Alkalinity, Magnesium, Calcium, Dissolved Oxygen (DO), Chemical Oxygen Demand (COD) and Biochemical Oxygen Demand (BOD) were selected for the assessment of WQI in this study.

\section{Quality Rating and Weight}

The quality of water has been examined by the view of the suitability of use by humans. The value of quality rating $\left(\mathrm{Q}_{\mathrm{n}}\right)$ of $\mathrm{nth}$ water quality parameters $(\mathrm{n}=1,2,3$,

$$
Q n=100\left(\frac{V n}{S n}\right)
$$

Where $\mathrm{V}_{n}=$ value of $n$th water quality parameter of sampling point and $\mathrm{S}_{\mathrm{n}}=$ Standard acceptable value of $n$th water quality parameters.

For the calculation of the value of quality rating of $\mathrm{pH}$ and $\mathrm{DO}$ need separate equation. The standard value of $\mathrm{pH}$ for drinking is 6.5 to 8.5 . So the value of quality rating of $\mathrm{pH}$ calculated by using eqn.-2.

$$
Q n=100\left[\frac{(V p H-6.5)}{8.5-6.5}\right]
$$

Equation (3) used for calculation of the value of quality rating $Q_{\text {Do. }}$.

$$
Q(D O)=100[(V(D O)-14.6) /(14.6-5)]
$$

The values of unit weight of nth water quality parameters:

$$
W n=k / S n
$$

Where $\mathrm{W}_{\mathrm{n}}=$ value of unit weight of $n$th water quality parameter $(\mathrm{n}=1,2,3 \ldots . .11), \mathrm{k}=$ proportionality constant

\section{Measurement of Water Quality Index (WQI)}

The Arithmetical Water Quality Index calculated by using the quality rating $Q_{n}$ and the unit weight Wn. Equation (5) used for calculation of the overall value of WQI. ${ }^{20-21}$

$$
W Q I=\sum_{n=1}^{11} Q n \cdot W n / \sum_{n=1}^{11} W n
$$

The value of WQI shows the status of the quality of water and it only shows the quality of water by single values.

\section{RESULTS AND DISCUSSION}

The data obtained in terms of water quality from seven sampling locations are presented in Table-2. The Temperature of water has extreme ecological consequences. 
RASĀYAN J. Chem.

Vol. 13 | No. 3 |1777-1784| July - September | 2020

Table-2: Experimental Values of Water Quality Parameters for the Study Areas

\begin{tabular}{c|c|c|c|c|c|c|c}
\hline Sample Code & $\mathrm{GW}_{1}$ & $\mathrm{GW}_{2}$ & $\mathrm{GW}_{3}$ & $\mathrm{GW}_{4}$ & $\mathrm{GW}_{5}$ & $\mathrm{GW}_{6}$ & $\mathrm{GW}_{7}$ \\
\hline Whether used for Drinking & YES & YES & YES & YES & YES & YES & YES \\
\hline Depth of Water Level (feet) & 200 & 250 & 180 & 300 & 220 & 280 & 250 \\
\hline Temperature & $27.5^{\circ} \mathrm{C}$ & $28^{\circ} \mathrm{C}$ & $28.5^{\circ} \mathrm{C}$ & $31^{\circ} \mathrm{C}$ & $29.5^{\circ} \mathrm{C}$ & $30.5^{\circ} \mathrm{C}$ & $28.5^{\circ} \mathrm{C}$ \\
\hline $\mathrm{pH}$ & 7.78 & 7.3 & 7.16 & 6.86 & 7.02 & 7.33 & 7.13 \\
\hline TDS (ppm) & 732 & 680 & 701 & 2150 & 973 & 450 & 750 \\
\hline TS (ppm) & 1050 & 1100 & 1200 & 4100 & 3500 & 600 & 1000 \\
\hline TSS (ppm) & 318 & 420 & 499 & 1950 & 2527 & 150 & 250 \\
\hline Turbidity (NTU) & 3 & 5 & 6 & 7 & 7 & 5 & 6 \\
\hline Total Hardness (ppm) & 60 & 260 & 265 & 865 & 365 & 205 & 325 \\
\hline Total Alkalinity (ppm) & 320 & 300 & 310 & 280 & 300 & 260 & 250 \\
\hline Chloride (ppm) & 68.16 & 88.75 & 92.3 & 599.95 & 142 & 49.7 & 88.75 \\
\hline DO (ppm) & 25.6 & 22.4 & 20.8 & 19.2 & 25.6 & 22.4 & 22.4 \\
\hline BOD (ppm) & 4.48 & 4.8 & 3.2 & 6.4 & 8 & 5.6 & 4.8 \\
\hline COD (ppm) & 6.4 & 14.4 & 6.4 & 16 & 4.8 & 8 & 52.8 \\
\hline Calcium (ppm) & 14 & 91.67 & 77.08 & 250 & 122 & 62.5 & 94 \\
\hline Megnesium (ppm) & 6 & 9.62 & 19.23 & 63.7 & 14.42 & 13.2 & 21.63 \\
\hline Total Acidity (ppm) & 15 & 15 & 15 & 25 & 20 & 10 & 10 \\
\hline
\end{tabular}

The variation in groundwater and the atmospheric temperature influences by the specific heat of the water. In this study, the temperature of groundwater was found to be 27.5 to 31 degrees Celsius. The lowest Temperature recorded was $27.5^{\circ} \mathrm{C}$ in a water sample near to Jaypee Cement Bhilai; however, the maximum Temperature observed was $31{ }^{\circ} \mathrm{C}$ in a water sample from Rajiv Nagar near ACC Company. The temperature of the water body was enhanced due to the mixing of hot waste coming from industrial unit. ${ }^{22} \mathrm{pH}$ based on the concentration of hydrogen ions; it is a scale for the intensity of acidity and alkalinity of water. In the present investigation, $\mathrm{pH}$ values of the groundwater are neutral or close to it as they all were ranged from 6.86 to 7.78 , which are within the permissible limits. Only one water sample has $\mathrm{pH}$ value 6.86 (less than 7), Sample from Rajiv Nagar, near ACC Company, Bhilai Industrial area. The maximum value recorded was 7.78 in the groundwater sample near Jaypee Cement Bhilai. TDS values are direct depends on inorganic salt and a low amount of organic compounds present in a sample of groundwater. This study represented a correlation between TDS vs. BOD, COD, Chloride, and Total Hardness; and shown by scatter plot in Fig.-2. It indicates a positive correlation among them except COD; this means as the value of TDS increased the value of BOD, Chloride and Total Hardness was also increased. ${ }^{24}$

The present study shows TDS value found to be range from 450 to $2150 \mathrm{ppm}$. The permissible level of TDS based on the WHO report is $500 \mathrm{ppm}$. TDS concentration below the permissible limit was found 450 ppm near to Shivnath Industry. Remain all samples have high TDS value as compared to an acceptable value. The maximum value of TDS was found to be $2150 \mathrm{ppm}$ in Rajiv Nagar near to ACC Company, Bhilai Industrial area, which shows higher pollution in water. Total dissolved Solids include factors that produce disease and oxygen demanding waste, which can be health hazardous. ${ }^{25}$ TS and TSS are also key factor for the determination of solid contamination in water samples. Turbidity directly measures the transparency of water. Turbid water is unfit for human consumption in terms of health hazardous. It ranges from 3 to 7 NTU/JTU. However, the standard value for drinking water of Turbidity is 5 NTU given by WHO. Values of Turbidity were found to be 3NTU, 5NTU, 6NTU, 7NTU, 7NTU, 5NTU and 6 NTU in sampling points $\mathrm{GW}_{1}, \mathrm{GW}_{2}, \mathrm{GW}_{3}, \mathrm{GW}_{4}, \mathrm{GW}_{5}, \mathrm{GW}_{6}$ and $\mathrm{GW}_{7}$ respectively. Total hardness indicates the hydrogeology and aesthetic quality of water. Hard water carries salt of $\mathrm{Ca}^{2+}, \mathrm{Mg}^{2+}, \mathrm{Fe}^{2+}$, $\mathrm{Mn}^{2+}$ are the most abounded in groundwater present in divalent and polyvalent metallic cations. Total Hardness values were observed from 60 to $865 \mathrm{ppm}$. The acceptable limit of Hardness in drinking water is $300 \mathrm{ppm}$. The highest value of Total Hardness recorded was $865 \mathrm{ppm}$ in $\mathrm{GW}_{4}$ sample, which indicates the water is unfit for drinking. The minimum value of Total Hardness observed was $60 \mathrm{ppm}$ in the groundwater $\mathrm{GW}_{1}$ sample. It represented a positive correlation with TDS. Calcium and Magnesium value 
RASĀYAN J. Chem.

Vol. 13 | No. 3 |1777-1784| July - September | 2020

are high in groundwater because of rapid Industrialization, Urbanization and industrial waste because industries used calcium and magnesium compounds. In this investigation, calcium and magnesium values were recorded between $14 \mathrm{ppm}-250 \mathrm{ppm}$ and $6 \mathrm{ppm}-63.70 \mathrm{ppm}$, respectively. In all samples, Phenolphthalein Alkalinity was nil, whereas Methyl Orange alkalinity was ranged between 250 to 320 ppm. For RCC work, Total Acidity should be less than $50 \mathrm{ppm}$. Total Acidity values were observed between 10 to $25 \mathrm{ppm}$. Chloride is widely distributed elements in all types of rocks. ${ }^{19}$ Maximum value of Chloride observed $599.95 \mathrm{ppm}$ in $\mathrm{GW}_{4}$ sample. BOD value in the study area varied from 3.2 to $8.0 \mathrm{ppm}$. However, the acceptable value for BOD is 6 ppm prescribed by Indian Standard ${ }^{23}$ and 5 ppm by WHO. The observed data indicated BOD values increase with the increase of TDS that formed a positive correlation. The COD estimates the total amount of oxygen used for oxidation of all organic compounds in water. The decomposition of organic compounds disturbs the aquatic life due to high COD value in water as a result of the depletion of oxygen. ${ }^{7}$ The COD value recorded from $4.80 \mathrm{ppm}$ to $52.80 \mathrm{ppm}$. However, the maximum acceptable limit of COD is $10 \mathrm{ppm}$ prescribed by Indian Standard. The maximum value of COD was found $52.80 \mathrm{ppm}$ in $\mathrm{GW}_{7}$ sample. Based on the individual value of WQI, the status of water quality of the sampling points is shown in Table-3.
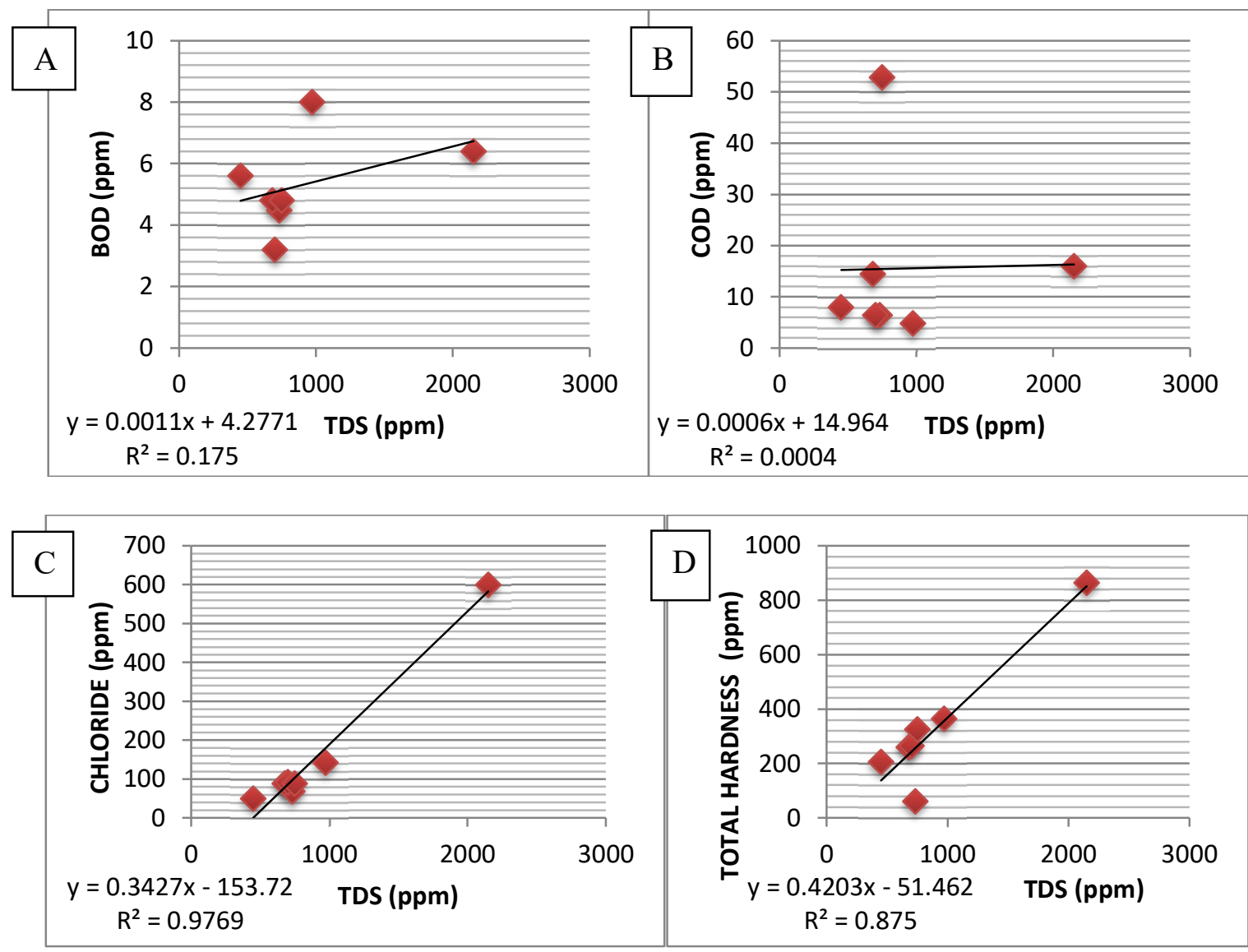

Fig.-2: Correlation between Water Quality Parameters

Standard values of Water Quality parameters recommended by Indian Standard/WHO with their potential effects are shown in Table-4. The quality of water is symbolized as a WQI. It found to be more than 100 in sample $\mathrm{GW}_{4}$ and $\mathrm{GW}_{7}$, which indicates the quality of water in that area found very poor and unfit for the consumption before proper treatment.

WQI found to be less than 100 in the remaining sample indicates the water quality of these areas have not polluted as compared to the above mentioned two areas, which have WQI more than 100. Variations of values of the Water Quality Index with their locations are shown in Fig.-3. 
RASĀYAN J. Chem.

Vol. 13 | No. 3 |1777-1784| July - September | 2020

Table-3: Water Quality Index for the Sampling Locations

\begin{tabular}{|c|c|c|c|c|c|c|c|c|c|c|c|c|c|c|c|c|}
\hline \multirow{3}{*}{$\begin{array}{l}\text { S. } \\
\text { N } \\
\text { o. }\end{array}$} & \multirow{3}{*}{$\begin{array}{l}\text { Water } \\
\text { Quality } \\
\text { Paramet } \\
\text { ers }\end{array}$} & \multicolumn{15}{|c|}{ Sampling Locations } \\
\hline & & \multirow[b]{2}{*}{$\mathrm{W}_{\mathrm{n}}$} & \multicolumn{2}{|l|}{$\mathrm{G}_{1}$} & \multicolumn{2}{|l|}{$\mathrm{G}_{2}$} & \multicolumn{2}{|l|}{$\mathrm{G}_{3}$} & \multicolumn{2}{|l|}{$\mathrm{G}_{4}$} & \multicolumn{2}{|l|}{$\mathrm{G}_{5}$} & \multicolumn{2}{|l|}{$\mathrm{G}_{6}$} & \multicolumn{2}{|l|}{$\mathrm{G}_{7}$} \\
\hline & & & $\mathrm{Q}_{\mathrm{n}}$ & $\begin{array}{l}\mathrm{Q}_{\mathrm{n}} \\
\mathrm{W}_{\mathrm{n}}\end{array}$ & $\mathrm{Q}_{\mathrm{n}}$ & $\begin{array}{l}\mathrm{Q}_{\mathrm{n}} \cdot \mathrm{W} \\
\mathrm{n}\end{array}$ & $\mathrm{Q}_{\mathrm{n}}$ & $\begin{array}{l}\mathrm{Q}_{\mathrm{n}} \\
\mathrm{W}_{\mathrm{n}}\end{array}$ & $\mathrm{Q}_{\mathrm{n}}$ & $\begin{array}{l}\mathrm{Q}_{\mathrm{n}} \cdot \mathrm{W} \\
\mathrm{n}\end{array}$ & $\mathrm{Q}_{\mathrm{n}}$ & $\begin{array}{l}\mathrm{Q}_{\mathrm{n}} \\
\mathrm{W}_{\mathrm{n}}\end{array}$ & $\mathrm{Q}_{\mathrm{n}}$ & $\begin{array}{l}\mathrm{Q}_{\mathrm{n}} \cdot \\
\mathrm{W}_{\mathrm{n}}\end{array}$ & $\mathrm{Q}_{\mathrm{n}}$ & $\mathrm{Q}_{\mathrm{n}} \cdot \mathrm{W}$ \\
\hline 1 & $\mathrm{pH}$ & 0.175 & 64 & $\begin{array}{l}11.1 \\
8 \\
\end{array}$ & 40 & 6.99 & 33 & 5.77 & 18 & 3.15 & 26 & 4.54 & 41.5 & 7.25 & 31.5 & 5.5 \\
\hline 2 & $\begin{array}{l}\text { Total } \\
\text { Dissolve } \\
\text { d Solid }\end{array}$ & 0.003 & $\begin{array}{l}146 . \\
4\end{array}$ & 0.38 & 136 & 0.36 & $\begin{array}{l}140 . \\
2\end{array}$ & 0.37 & 430 & 1.13 & $\begin{array}{l}194 . \\
6\end{array}$ & 0.51 & 90 & 0.24 & 150 & 0.39 \\
\hline 3 & $\begin{array}{l}\text { Turbidit } \\
\mathrm{y}\end{array}$ & 0.262 & 60 & $\begin{array}{l}15.7 \\
3 \\
\end{array}$ & 100 & 26.21 & 120 & $\begin{array}{l}31.4 \\
5 \\
\end{array}$ & 140 & 36.7 & 140 & 36.7 & 100 & $\begin{array}{l}26.2 \\
1 \\
\end{array}$ & 120 & 31.45 \\
\hline 4 & $\begin{array}{l}\text { Total } \\
\text { Hardnes } \\
\text { s }\end{array}$ & 0.004 & 20 & 0.09 & $\begin{array}{l}86 . \\
7\end{array}$ & 0.38 & $\begin{array}{l}88.3 \\
3\end{array}$ & 0.39 & $\begin{array}{l}288 . \\
3\end{array}$ & 1.26 & $\begin{array}{l}121 \\
7\end{array}$ & 0.53 & $\begin{array}{l}68.3 \\
3\end{array}$ & 0.3 & $\begin{array}{l}108 \\
3\end{array}$ & 0.47 \\
\hline 5 & $\begin{array}{l}\text { Total } \\
\text { Alkalinit } \\
\mathrm{y}\end{array}$ & 0.007 & 160 & 1.05 & 150 & 0.98 & 155 & 1.02 & 140 & 0.92 & 150 & 0.98 & 130 & 0.85 & 125 & 0.82 \\
\hline 6 & Calcium & 0.017 & $\begin{array}{l}18.6 \\
6 \\
\end{array}$ & 0.33 & 122 & 2.14 & $\begin{array}{l}102 . \\
8\end{array}$ & 1.8 & $\begin{array}{l}333 . \\
3\end{array}$ & 5.82 & $\begin{array}{l}162 . \\
7 \\
\end{array}$ & 2.84 & $\begin{array}{l}83.3 \\
3 \\
\end{array}$ & 1.46 & $\begin{array}{l}125 . \\
3\end{array}$ & 2.19 \\
\hline 7 & $\begin{array}{l}\text { Magnesi } \\
\text { um }\end{array}$ & 0.044 & 20 & 0.87 & $\begin{array}{l}32 . \\
1\end{array}$ & 1.4 & 64.1 & 2.8 & $\begin{array}{l}212 . \\
3\end{array}$ & 9.28 & $\begin{array}{l}48.0 \\
7 \\
\end{array}$ & 2.1 & $\begin{array}{l}44.0 \\
6 \\
\end{array}$ & 1.92 & 72.1 & 3.15 \\
\hline 8 & Chloride & 0.005 & $\begin{array}{l}27.2 \\
6 \\
\end{array}$ & 0.14 & $\begin{array}{l}35 . \\
5 \\
\end{array}$ & 0.19 & $\begin{array}{l}36.9 \\
2 \\
\end{array}$ & 0.19 & 240 & 1.26 & 56.8 & 0.3 & $\begin{array}{l}19.8 \\
8 \\
\end{array}$ & 0.1 & 35.5 & 0.19 \\
\hline 9 & $\begin{array}{l}\text { Dissolve } \\
\mathrm{d} \\
\text { Oxygen }\end{array}$ & 0.134 & $\begin{array}{l}114 . \\
6\end{array}$ & $\begin{array}{l}15.3 \\
2\end{array}$ & $\begin{array}{l}81 . \\
3\end{array}$ & 10.87 & $\begin{array}{l}131 . \\
3\end{array}$ & $\begin{array}{l}17.5 \\
5\end{array}$ & 47.9 & 6.41 & $\begin{array}{l}114 . \\
6\end{array}$ & $\begin{array}{l}15.3 \\
2\end{array}$ & $\begin{array}{l}81.2 \\
5\end{array}$ & $\begin{array}{l}10.8 \\
7\end{array}$ & $\begin{array}{l}81.2 \\
5\end{array}$ & 10.87 \\
\hline 10 & $\begin{array}{l}\text { Biochem } \\
\text { ical } \\
\text { Oxygen } \\
\text { Demand }\end{array}$ & 0.218 & $\begin{array}{l}74.6 \\
6\end{array}$ & $\begin{array}{l}16.3 \\
1\end{array}$ & 80 & 17.47 & 120 & $\begin{array}{l}26.2 \\
1\end{array}$ & $\begin{array}{l}106 \\
7\end{array}$ & 23.3 & $\begin{array}{l}133 . \\
3\end{array}$ & $\begin{array}{l}29.1 \\
3\end{array}$ & $\begin{array}{l}93.3 \\
3\end{array}$ & $\begin{array}{l}20.3 \\
9\end{array}$ & 80 & 17.47 \\
\hline 11 & $\begin{array}{l}\text { Chemica } \\
1 \\
\text { Oxygen } \\
\text { Demand }\end{array}$ & 0.131 & 64 & 8.39 & 144 & 18.87 & 64 & 8.39 & 160 & 20.97 & 48 & 6.29 & 80 & $\begin{array}{l}10.4 \\
8\end{array}$ & 528 & 69.2 \\
\hline & & $\begin{array}{l}\sum \mathrm{Wn}= \\
1.00\end{array}$ & \multicolumn{2}{|c|}{$\begin{array}{l}\sum_{69.79} \mathrm{Q}_{\mathrm{n}} \cdot \mathrm{W}_{\mathrm{n}}= \\
69.7\end{array}$} & \multicolumn{2}{|c|}{$\begin{array}{l}\sum_{85.86} \mathrm{Q}_{\mathrm{n}} \cdot \mathrm{W}_{\mathrm{n}}= \\
\end{array}$} & \multicolumn{2}{|c|}{$\begin{array}{l}\sum_{95.93} Q_{n} \cdot W_{n}= \\
\end{array}$} & \multicolumn{2}{|c|}{$\begin{array}{l}\sum_{1} Q_{n} \cdot W_{n}= \\
110.18\end{array}$} & \multicolumn{2}{|c|}{$\begin{array}{l}\sum_{99.25} Q_{n} \cdot W_{n}= \\
99.25\end{array}$} & \multicolumn{2}{|c|}{$\begin{array}{l}\sum_{80.07} Q_{n} \cdot W_{n}= \\
\end{array}$} & \multicolumn{2}{|c|}{$\begin{array}{l}\sum_{141.71} Q_{n} \cdot W_{n}= \\
141\end{array}$} \\
\hline \multicolumn{3}{|c|}{ Water Quality Index } & \multicolumn{2}{|l|}{69.79} & \multicolumn{2}{|c|}{85.86} & \multicolumn{2}{|l|}{95.93} & \multicolumn{2}{|c|}{110.18} & \multicolumn{2}{|c|}{99.25} & \multicolumn{2}{|l|}{80.07} & \multicolumn{2}{|c|}{141.71} \\
\hline
\end{tabular}

Table-4: Water Quality Parameters and their Potential Effects.

\begin{tabular}{|c|c|c|c|c|c|}
\hline S. No. & $\begin{array}{l}\text { Water Quality } \\
\text { Parameter }\end{array}$ & $\begin{array}{l}\text { Standard } \\
\text { Values } \\
\text { (WHO/IS) }\end{array}$ & $\begin{array}{l}\text { Samples Code (where values } \\
\text { found high as compare } \\
\text { permissible limit) }\end{array}$ & Potential Effects & Reference \\
\hline 1 & $\mathrm{pH}$ & $6.5-8.5$ & Nil & $\begin{array}{l}\text { Skin Disorder, affect mucous membranes, } \\
\text { bitter test, Corrosion of metal }\end{array}$ & $9,26,27$ \\
\hline 2 & $\begin{array}{l}\text { Total Dissolved } \\
\text { Solid }\end{array}$ & $500 \mathrm{ppm}$ & $\begin{array}{l}\mathrm{GW}_{1}, \mathrm{GW}_{2}, \mathrm{GW}_{3}, \mathrm{GW}_{4}, \\
\mathrm{GW}_{5}, \mathrm{GW}_{7}\end{array}$ & $\begin{array}{l}\text { Undesirable taste, Coronary heart disease, } \\
\text { arteriosclerotic heart disease, } \\
\text { Cardiovascular disease }\end{array}$ & 9,28 \\
\hline 3 & Turbidity & $5 \mathrm{NTU}$ & $\mathrm{GW}_{3}, \mathrm{GW}_{4}, \mathrm{GW}_{5}, \mathrm{GW}_{7}$ & $\begin{array}{l}\text { Increasing Micro-organisms, gastrointestinal } \\
\text { illness } \\
\text { and disease-causing bacteria's }\end{array}$ & 29 \\
\hline 4 & Total Hardness & $300 \mathrm{ppm}$ & $\mathrm{GW}_{1}, \mathrm{GW}_{4}, \mathrm{GW}_{5}, \mathrm{GW}_{7}$ & $\begin{array}{l}\text { Cardiovascular disease, Risk of gastric } \\
\text { cancer, Central nervous system, } \\
\text { Alzheimer's disease, diabetes, Poor } \\
\text { lathering with soap, deterioration of the } \\
\text { quality of clothes, scale forming }\end{array}$ & 12,30 \\
\hline 5 & Total Alkalinity & $200 \mathrm{ppm}$ & All Samples & $\begin{array}{l}\text { Digestion problems, Embrittlement of boiler } \\
\text { steel, } \\
\text { Boiled rice turns yellowish }\end{array}$ & 9 \\
\hline 6 & Calcium & $75 \mathrm{ppm}$ & $\mathrm{GW}_{2}, \mathrm{GW}_{3}, \mathrm{GW}_{4}, \mathrm{GW}_{5}, \mathrm{GW}_{7}$ & $\begin{array}{l}\begin{array}{l}\text { Interference in dyeing, textiles, } \\
\text { hypercalcemia }\end{array} \\
\end{array}$ & 28 \\
\hline 7 & Magnesium & $30 \mathrm{ppm}$ & $\mathrm{GW}_{4}$ & $\begin{array}{l}\text { Diarrhoea, hypermagnesaemia, } \\
\text { Paper Industries affected }\end{array}$ & 28 \\
\hline 8 & Chloride & $250 \mathrm{ppm}$ & $\mathrm{GW}_{4}$ & Hypertension, eye/nose irritation & 9,10 \\
\hline 9 & $\begin{array}{l}\text { Dissolved } \\
\text { Oxygen }\end{array}$ & $\begin{array}{l}5 \text { to } 14.6 \\
\text { Ppm }\end{array}$ & Nil & $\begin{array}{l}\text { Corrode water lines, boilers and heat } \\
\text { exchangers, } \\
\text { low-level marine animals cannot survive. }\end{array}$ & 31 \\
\hline
\end{tabular}


RASĀYAN J. Chem.

Vol. 13 | No. 3 |1777-1784| July - September | 2020

\begin{tabular}{l|l|l|l|l|l}
\hline 10 & $\begin{array}{l}\text { Biochemical } \\
\text { Oxygen } \\
\text { Demand }\end{array}$ & $6 \mathrm{ppm}$ & $\mathrm{GW}_{4}, \mathrm{GW}_{5}$ & $\begin{array}{l}\text { Causes of Human health Problems, } \\
\text { Decrease level of Oxygen. }\end{array}$ & \begin{tabular}{l} 
Causes of Human Health Problems \\
\hline 11
\end{tabular} \\
\hline $\begin{array}{l}\text { Chemical } \\
\text { Oxygen } \\
\text { Demand }\end{array}$ & $10 \mathrm{ppm}$ & $\mathrm{GW}_{2}, \mathrm{GW}_{4}, \mathrm{GW}_{7}$ & 31 \\
\hline
\end{tabular}

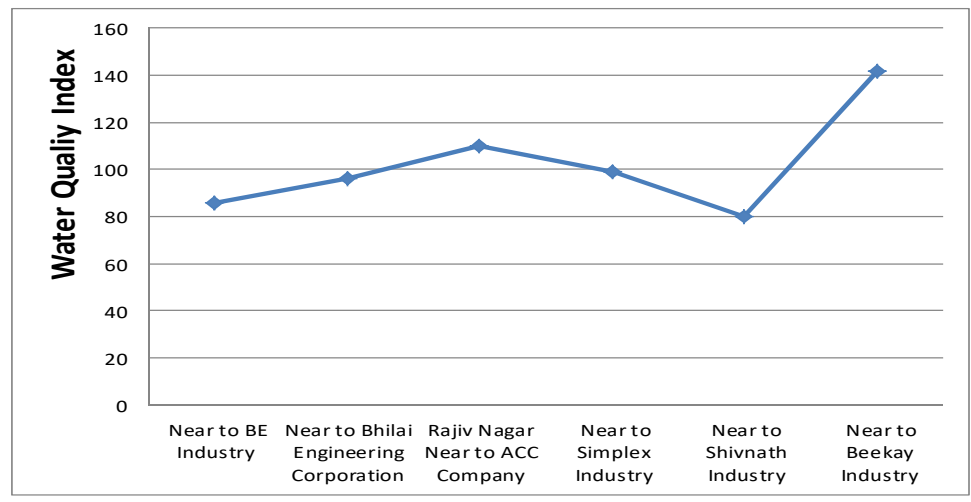

Fig.-3: Variation of Values of Water Quality Index with their Location

\section{CONCLUSION}

The present study indicates the water samples from near to BE industry, Bhilai Engineering Corporation, Simplex and Shivnath industry are not suitable for daily consumption due to very poor quality with high WQI. Among all water samples near the ACC Company and the Beekay industry are indicates the very worst quality due to the water quality index value is more than 100 . Some water quality parameters are strong or weak associated with each other. Proper continue observation of water quality is required to monitor the suitability for drinking purposes. This study will be useful for policymakers for implementing monitoring industry wastewater treatment and management adopted in the industry. Authors suggest either the residence situated far away from industries or use properly treated water.

\section{ACKNOWLEDGMENT}

We are thankful to the Principal and Management of Chhattisgarh Engineering College for providing the laboratory facilities.

\section{REFERENCES}

1. A. I. Khwakaram, S. N. Majid and N. Y. Hama, International Journal of Plant, Animal and Environmental Sciences, 2(4), 148(2012).

2. A. Aziz, N. T. Mahmood, M. Habibullah and M. Amanullah, Journal of Environmental Professionals Sri Lanka, 2(1), 52(2013).

3. M. Sureshkumar, R. Sivakumar, and M. Nagarajan, Rasayan Journal of Chemistry, 9(3), 454(2016)

4. A. Sonkar, and A. Jamal, Rasayan Journal of Chemistry, 11(3), 1270(2018), DOI: 10.31788/RJC.2018.1134026

5. D. Kumar, V. Kumar, and S. Kumari, Rasayan Journal of Chemistry, 11(4), 1477(2018), DOI: 10.31788/RJC.2018.1143075

6. A. M. Shala Abazi, B. H. Durmishi, F. S. Sallaku, H. S. Çadraku, O. B. Fetoshi, P. H. Ymeri and P. S. Bytyci, Rasayan Journal of Chemistry, 13(1), 146(2020), DOI:10.31788/RJC.2020.1315344

7. H. M. Mohamed and Z. Hussain A., International Research Journal of Environmental Sciences, 2(1), 68(2013).

8. WHO, Guidelines for drinking water quality-I, Recommendations, $2^{\text {nd }}$ Ed. Geneva (1993).

9. WHO, Guidelines for drinking-Water quality, Health criteria and other supporting information, Geneva (2003).

10. WHO, Protecting Health from Climate change, Connecting science, policy and people (2009).

11. N. Bharti, D. Katyal, International Journal of Environment Sciences, 2(1), 154(2011).

12. N. C. Das, International Research Journal of Environmental Science, 2(11), 96(2013). 
RASĀYAN J. Chem.

Vol. 13 | No. 3 |1777-1784| July - September | 2020

13. J. Yadav, R. K. Pathak and E. Khan, International Research Journal of Environmental Sciences, 2(1), 9(2013).

14. Census Data, Meta Data, Ministry of Home Affair, Government of India, (2011).

15. V. H. Reddy, P. M. N. Prasad, A. V. Ramana Reddy and Y. V. Rami Reddy, Der Pharma Chemica, 4(6), 2442(2012).

16. M. K. Jindal and M. Upadhyay, Journal of Pharmaceutical and Biomedical Sciences, 4(1), 22(2014).

17. M. K. Jindal, P. Deshmukh and R. Tamrakar, International Research Journal of Environmental Sciences, 3(5), 44(2014).

18. APHA, Standard Method For Examination of Water and Waste Water, American Public Health Association, Washington, DC, (1989).

19. $\mathrm{R}$ Mangukiya, $\mathrm{T}$ Bhattacharya and $\mathrm{S}$ Chakraborty, International Research Journal of Environmental Sciences, 1(4), 14(2012).

20. A. Q. Dar, S. Saima and G. Saqib, IOSR Journal of Mechanical and Civil Engineering, 51-58 (2014).

21. M. Bora, D. C. Goswami, Applied Water Science, 7, 3125(2017), DOI:10.1007/s13201-016-0451-y

22. D. Singh and A. K. Jangde, International Research Journal of Environmental Sciences, 2(3), 41(2013).

23. IS:10500, Indian Standard Specifications for Drinking Water (2012).

24. S. K. Sar, M. Sahu, S. Singh, V. Diwan, M. Jindal and A. Arora, Journal of Radioanalytical and Nuclear Chemistry, 314, 2339(2017), DOI:10.1007/s10967-017-5587-1

25. D. Shinde and N. U. Singh, International Research Journal of Environmental Sciences, 2(11), 72(2013).

26. H. Mahobe and P. Mishra, International Journal of Scientific \& Engineering Research, 4(8), 738(2013).

27. K. A. Shah and G. S. Joshi, Applied Water Science, 7, 1349(2017), DOI:10.1007/s13201-015-0318-7

28. M. Yirdaw and A. Bamlaku, Environmental System Research, 5(1), (2016), DOI:10.1186/s40068016-0053-6

29. S. C. Tinker, M. L. Christine, M. Klein, F. W. Dana, J. Uber, A. Appiah, S. Philip and T. E. Paige, Journal of Exposure Science \& Environmental Epidemiology, 20(1), 19(2010), DOI: $10.1038 /$ jes. 2008.68

30. P. Sengupta, International Journal of Preventive Medicine, 4(8), 866(2013).

31. P. N. Patil, D. V. Sawant and R. N. Deshmukh, International Journal of Environmental Science, 3(3), (2012).

[RJC-5853/2020] 